\title{
Social segregation of indigenous migrants in Mexico: An overview from Monterrey
}

In Mexico, rural-to-urban migration is a clearly noticeable phenomenon. During the last few years, there has been spontaneous growth in the migration of indigenous people towards the northern cities of Mexico, especially to Monterrey, in search of employment. Once the migrants arrive in this metropolis, they face difficulties adjusting and adapting to the city environment because of hidden discrimination. The main argument and hypothesis of this paper is that indigenous people isolate themselves and segregate themselves socially due to fear of (cultural and racial) discrimination and violence. For this study, data were obtained from fieldwork carried out during 2009 and 2010 in Monterrey, Mexico, where we interviewed 350 indigenous people that had moved there from different parts of the country.

Key words: internal migration, indigenous people, discrimination, social segregation, Mexico 


\section{Introduction}

Urbanisation and migration have come to be regarded as the most pressing population problems in developing countries, even more pressing than high fertility and natural population growth rates (United Nations, 2010). A look at history shows that the human population mostly lived a rural lifestyle, dependent on agriculture and hunting for survival. In 1800, only $3 \%$ of the world's population lived in urban areas. By 1900 , almost $14 \%$ were urbanites, although only twelve cities had one million or more inhabitants. By 1950,30\% of the world's population resided in urban centres and the number of cities with over one million people had grown to eighty-three. The world has experienced unprecedented urban growth in recent decades. In 2008, for the first time, the world's population was evenly split between urban and rural areas. There were more than 400 cities over one million and nineteen over ten million. More-developed nations were about $74 \%$ urban, whereas $44 \%$ of residents of less-developed countries lived in urban areas. However, urbanisation is occurring rapidly in many less-developed countries due to high rural urban migration. It is expected that $70 \%$ of the world population will be urban by 2050, and that most urban growth will occur in less-developed countries (Population Reference Bureau, 2012).

In the case of Mexico, migration from rural to urban areas is a common occurrence. In most rural areas, rural-to-urban migration is a factor in the rapid deterioration of the primary sector, chronic poverty and low development of the agricultural sector. Today, nearly seventy-nine million Mexicans (out of 110 million) live in various urban centres, out of which nearly $60 \%$ live in three metropolitan cities: Mexico City, Guadalajara and Monterrey (Instituto Nacional de Estadísticas y Geografía, INEGI, 2011). Although Mexico is well known for its international migration flow (from Mexico to the U.S.), the recent regional economic disparities in the country have emerged as the main reason for internal migration, which is mainly dominated by indigenous people. Mexico has the largest indigenous population in Latin America, although their proportion compared to the total population is less (10\% of the country's population; INEGI, 2011). Around $80 \%$ of indigenous people are located in the southern part of the country, in the states of Campeche, Chiapas, Guerrero, Hidalgo, Oaxaca, Puebla, Quintana Roo, Tabasco, Tlaxcala, Veracruz and Yucatán, and nearly 15\% live in central Mexico (in Aguascalientes, Colima, Guanajuato, Jalisco, México, Michoacan, Morelos, Nayarit, Querétaro, San Luis Potosí, Sinaloa and Zacatecas; Hall \& Patrinos, 2005).

A study carried out by United Nations Human Settlements Programmes (UN-HABITAT) titled "Urban indigenous peoples and migration: A review of policies, programmes and

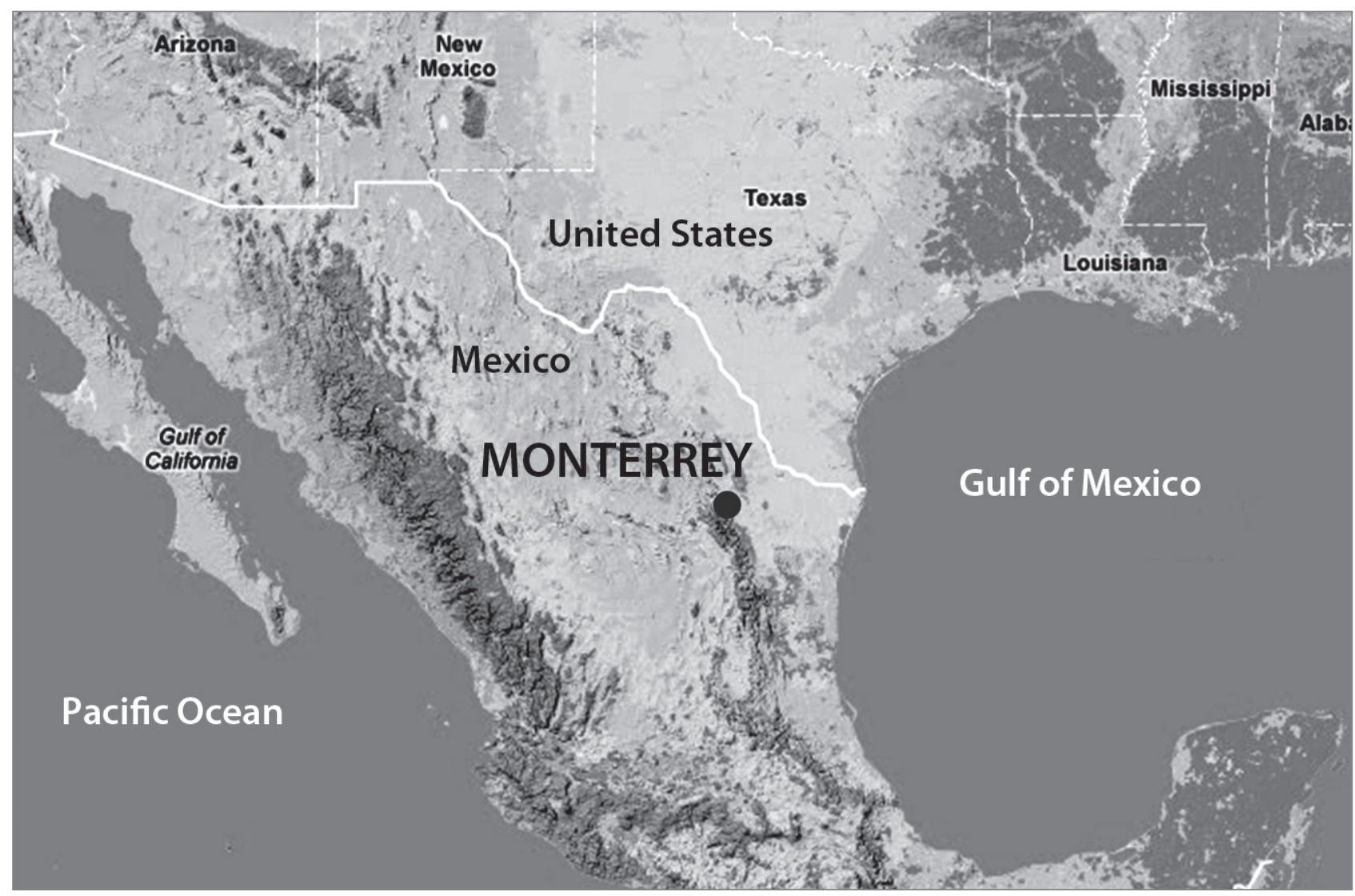

Figure 1: Map of Mexico and Monterrey (source: Internet 1). 
practices" indicated that the indigenous population in Mexico is predominantly rural, but is currently becoming urban due to migration (UN-HABITAT, 2010). According to the Na-
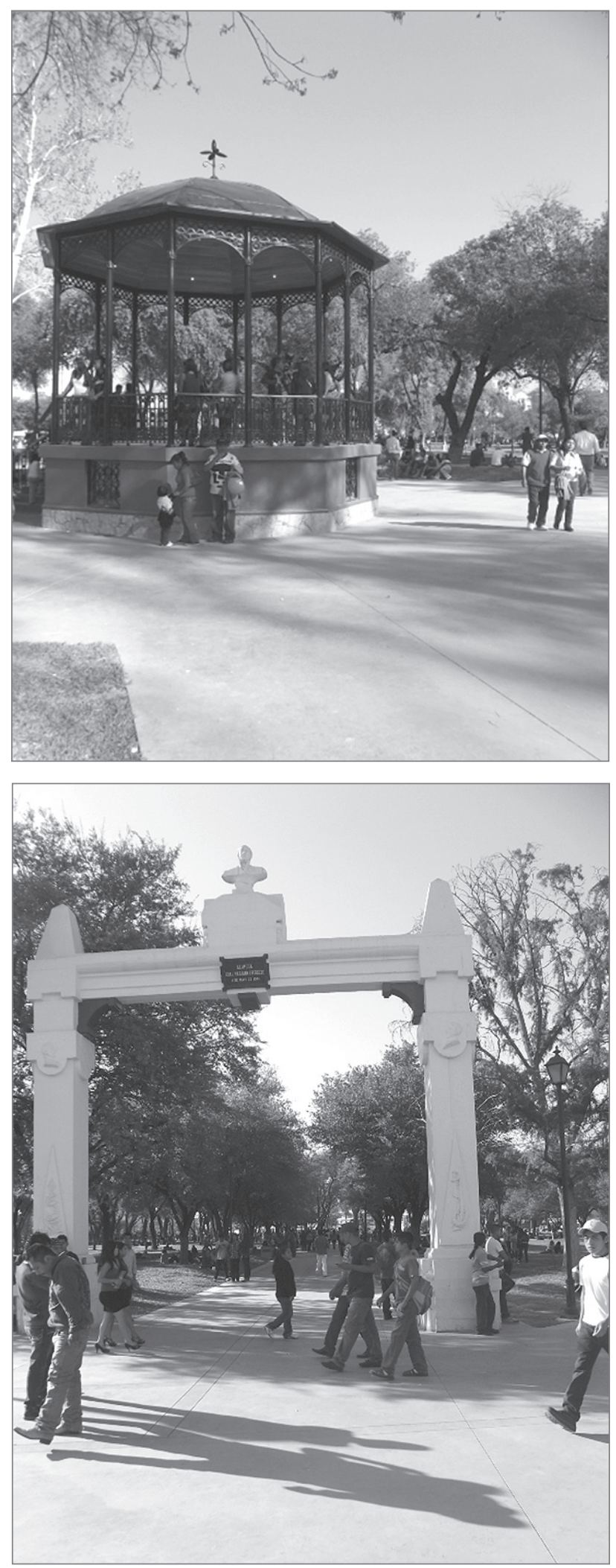

Figure 2: Alameda, Monterrey, Mexico (photo: Arun Kumar Acharya). tional Commission for the Development of Indigenous People (Span. Comisión Nacional para el Desarrollo de los Pueblos Indigenas, $\mathrm{CDI}$ ) indigenous people in cities have on average less schooling, fewer economic resources, more arduous jobs and lower salaries than the rest of the population (Immigration and Refugee Board of Canada, 2008). Studies by Maya Lorena Pérez Ruiz (2007) stated that indigenous people largely migrate to Mexico City; however, today there is a high presence of these people in northern cities; for example, Monterrey, Tijuana and Ciudad Juárez. Authors such as Pérez Ruiz (2007) and Séverin Durin et al. (2007) indicate that indigenous migrants settle on the margins of these cities, where they can practice their cultural and kinship customs because these traditional elements are out of context in the present urban way of life. On the other hand, studies carried out by Olimpia Farfán and Ismael Fernández (2001), Nicte Há Dzib (2003) and Durin (2003) indicate that indigenous people suffer from many disadvantages as well as discrimination upon their arrival in urban centres. These indigenous migrants report high levels of perceived discrimination attributed to their racial/ cultural identities, which along with the presence of certain culture-bound syndromes places them at significant risk for depression. Thus, our argument and hypothesis for this study is that indigenous people in the city isolate themselves and segregate themselves socially due to fear of discrimination and violence. The main objective of this study is to analyse the kind of discrimination suffered by indigenous migrants in Monterrey and how discrimination causes social segregation.

For this study we interviewed 350 indigenous migrants in Monterrey during 2009 and 2010 using the snowball method. In the first instance, we contacted an indigenous person in Alameda ${ }^{[1]}$ in order to talk with him regarding the purpose of our study and asked for an interview. After the interview, we asked him to introduce us to other indigenous people he knew (for interviews). In the same day he put us in contact with three other people that we interviewed, and with the help of these three people we identified some other indigenous migrants. Using this methodology, 350 indigenous persons (210 male and 140 female) were interviewed with a structured questionnaire at Alameda (see Figure 1a). This paper is divided into three parts. The first part outlines the theoretical models that explain the reason for migration, and the second part looks at the associated factors and causes of indigenous migration towards Monterrey. The paper concludes with an analysis of discrimination faced by indigenous migrants in Monterrey and how it affects social segregation.

\section{Theoretical model on migration}

The phenomenon of migration is not new. Throughout history, human beings have migrated from one place to another 
in search of land or food. The causes of migration are numerous and so are the consequences. Some scholars, such as Ernest George Ravenstein, have explained that major causes of migration are economic; whereas other scholars, such as Everett Lee, have explained that migration depends on four factors: a) factors operating at the place of origin, b) factors operating at the destination, c) factors that act as intervening obstacles and d) personal factors that are specific to an individual (Husain, 1994). Ravenstein's laws of migration and Lee's migration theory broadly explain the causes of migration, but there are other migration models such as the dual economy model, Michael P. Todaro's model of rural urban migration and push-pull factors, which explain that migration occurs when the predicted discounted future income stream available at a potential destination is greater than the discounted future income stream at the person's current location plus the cost of migration. Individuals may therefore choose to move if they see another area giving them a greater opportunity for employment or pay.

\subsection{Dual economy and the causes of rural to urban migration}

Theoretically, migration is simply defined as a process of personal movement from one area to another. However, the nature of migration and the causes for it are complex, and there is no general agreement among researchers on the causes of migration. Arguments on the differences between factors causing migration exist not only among researchers from various disciplines, but also among researchers within a discipline. Economists consider rural-to-urban migration to be a process of labour movement from less-developed areas towards more advanced ones. In 1954 Arthur Lewis explained the dual economy theory, referring to rural areas as the agricultural sector where the labour force is suffering from unemployment and underemployment, and modernised areas: the industrial sector where many employment opportunities are generated and are also suffering from a labour shortage. Along the development course, the industrial sector is expanding and it requires increasingly more labour, whereas the agricultural sector is stagnant and has a labour surplus. Under these circumstances, the labour surplus in rural areas will supplement the labour shortage in urban areas, and in this way rural-to-urban migration begins. In the subsistence sector the marginal productivity of labour is very low and workers are usually paid subsistence wages, hence wage rates in this sector barely exceed marginal products. Contract wages in the modern urban sector are much higher. Due to the differences in wage rates, migration occurs from the subsistence sector to the industrial sector. As long as the industrial process starts in urban areas, the labour demand keeps rising, and therefore it triggers labour demand from the subsistence sector. This process continues until the wage difference between subsistence and advanced areas becomes zero.

Although the dual economy theory convincingly explains the cause of rural-to-urban migration as a result of wage-rate differences, many other researchers have found it unsatisfactory because of a number of shortcomings (Todaro, 1976). First, although wage-rate differences are an important reason for a person to move from a rural area to an urban one, the movement of people from rural to urban areas should not simply be seen as a case of wage differences. There are many other issues that force people to relocate. Second, many people believe that the assumption of zero marginal productivity and labour surplus in rural areas is not very realistic. Third, the assumption that the rate of job generation in urban areas is high enough to absorb the labour from rural areas is not true in many cases. In general, industrialisation in urban areas creates a high demand for labour, but today, under the strong threat of competition, many firms have not employed labour-intensive technology, but capital-intensive instead, and therefore the demand for labour in urban areas is not always high enough to absorb labour from rural areas. Finally, some studies argue that migration from rural areas to urban areas, as observed from reality, does not always go to the industrial sector as in Lewis's theory, but simply comes to urban areas to work in low-productivity and low-wage sectors in the informal economy of the city such as street vendors, casual labourers or construction workers. All of these points indicate that, although the neoclassical theory has explained the causes for a person to move from a rural area to an urban one, it has oversimplified the causes of migration. Lewis's model could explain the western model well, but it does not fully explain the current rural-to-urban migration in the developing world. A special feature of the developing world today is high population growth, and therefore migration from rural to urban areas is not only because of wage differences and labour demand in urban areas.

\subsection{Todaro's model of rural-to-urban migration}

During the 1970s, Todaro published a number of papers on migration-related issues, and his papers have contributed greatly to the understanding of migration. He explains that rural-to-urban migration continues to exceed the rates of job creation and to greatly surpass the capacity of both industry and urban social services to absorb this labour effectively (Todaro, 1976). For Todaro, rural-to-urban migration in developing countries today is not a process of equalising the wage-rate differences between rural and urban areas; on the contrary, migration today is increasingly being viewed as the major contributing factor to the ubiquitous phenomenon of urban surplus labour and a force that continues to exacerbate the already serious urban unemployment problems caused by 
growing economic and structural imbalances between urban and rural areas (Ayman, 2002). Todaro suggests that the decision to migrate includes the perception on the part of potential migrants of a potentially higher urban income, which will give them a better income and therefore a better livelihood (Cornwell, 2004).

According to Todaro's approach, migration rates in excess of the growth of urban job opportunities are not only possible, but also rational and probable in the face of continued and expected large positive urban-to-rural income differentials. High levels of rural-to-urban migration can continue even when urban unemployment rates are high and are known to potential migrants. Todaro suggests that a migrant will move even if that migrant ends up being unemployed or receives a lower urban wage than the rural wage. This happens because migrants expect that they will end up with some kind of job that gives them good compensation, and therefore they are willing to be unemployed or underpaid and to wait for a better job opportunity in the future. This argument explains the high flow of migrants from rural to urban areas that come to urban areas but end up unemployed. A major weakness of Todaro's model is its assumption regarding expected incomes because it is unrealistic to expect migrants to have enough information to project and make a decision to move to urban areas. Todaro's models do not take into account non-economic factors and they are abstracted from the structural aspects of the economy (Ayman, 2002).

\subsection{The push and pull factors approach}

To some extent, the pull and push factors approach to finding the cause of rural-to-urban migration is a combination of the neoclassical approach and Todaro's approach. Lee (1966) developed a general schema into which a variety of spatial movements can be placed, based on the arguments in which he divided the forces influencing migrant perceptions into push and pull factors (Ayman, 2002). The former are negative factors tending to force migrants to leave their areas of origin, and the latter are positive factors attracting migrants to destination areas in the expectation of improving their standard of living. According to Lee (1966), the push factor could be more important than the pull factor - that is, difficulties in rural areas, such as poverty, unemployment and land shortages, which are driving forces that compel farmers to leave their native area to find a new place to settle and work. These push factors are the basic factors that produce migration. The pull factors refer to job or income opportunities outside the farmers' homeland that are so attractive that people cannot stay where they are. By these means, the job and income opportunities in urban areas or advanced sectors are pull factors that pull people to urban areas to settle and work. Although migration can be produced either by push or pull factors, according to Lee migration mostly is a result of a combination of both push and pull factors that are associated with the areas of origin and the destination, and are also governed by personal factors that affect individual thresholds and facilitate or impede migration.

The migration models above give a clear view of how better employment opportunities and better living conditions are the main reason why people move from one place to another. However, once migrants arrive in a new society, they face many disadvantages in assimilating into the receiving society. The difficulty of assimilation increases due to a wide gap in wealth and status between migrants and the receiving society. Some studies indicate that although people belong to the same nation they may face isolation from others due to their cultural norms, language, skin colour and place of birth. The classical model of migrant residential incorporation, which was developed in spatial assimilation theory, has theoretical roots in neo-classical economics and historical roots in the urban experience of earlier migrant waves (Fong \& Gulia, 1999; Massey \& Denton, 1985). The theory indicates that new migrants always cluster due to economic and social reasons. New migrants always face discrimination and exclusion due to their economic standards as well as their cultural and social backgrounds. However, once migrants acquire greater economic resources and adopt the culture of the receiving society, migrants eventually begin to assimilate. On the other hand, few social phenomena have been as thoroughly measured as racial residential segregation. Studies have documented the extent of racial segregation (Taeuber \& Taeuber, 1965; Massey \& Denton, 1993), considered measurement issues at length (White, 1986; Massey \& Denton, 1988) and charted changes in the extent of segregation over time (Farley \& Frey, 1994; Cutler et al., 1999; Márquez, 2011).

\section{Indigenous migration in Mexico}

Today migration is an important aspect of economic development, both for the place of origin and the destination. Literature on internal migration in Mexico indicates that it has grown noticeably over the last century due to fewer opportunities in the rural economy, causing rural people to move to urban areas. Over the last 100 years, Mexico has experienced a transition from a rural economy to an urban one. Consistent with that trend, today less than $23 \%$ of the population lives in rural areas. However, poverty is more endemic to rural areas, where the worst cases of poverty are found, thus increasing migration (Mere, 2007).

Francisco Mere (2007) determined that rural migration to urban areas in Mexico has been an ongoing process. According to the author, rural to urban migration grew $182 \%$ from 1980 
to 1994 and 352\% between 1980 and 2002; however, rural migration to the U.S. grew $92 \%$ from 1980 to 1994 and it grew $452 \%$ from 1980 to 2002. On the other hand, the literature indicates that intensive indigenous migration began during the 1940s. For example, a study by Jonathan Fox and Gaspar Rivera Salgado (2004) states that the P'urhépecha people migrated first to northern Mexico and the southern United States from the Mexican state of Michoacán. The Bracero Program encouraged these first movements in North America. Impoverished communities from the southern Mexican states travelled in search of employment opportunities to agricultural areas on the west coast of the United States, mostly in California. Indigenous peoples took part in this program, but their experience has not been specifically documented, and for the most part they were categorised without further differentiation from other peasants. Reasons for rural-urban migration are diverse, as are the conditions and effects of the migration experience. Some of the available data and literature describe the migratory conditions as voluntary or involuntary; that is, forced (Sema, 2007; UN-HABITAT, 2007). Studies and policies also recognise the multiple push and pull factors of urban mobility and highlight a range of contributory factors that overlap socioeconomic, cultural, developmental and political matters (Del Popolo, 2007; Kipuri, 2007). Some indigenous persons, for example, are motivated by opportunities in urban areas for "improved job employment, health, housing, education, political participation, social recognition and visibility or other benefits that they may lack in their territories". Others are pushed to the cities by poverty, lack of water supplies and the deterioration of traditional lifestyles and environmental degradation (United Nations Permanent Forum on Indigenous Issues, UNPFII, 2008).

In the case of Mexico, underdevelopment among other things is a main driving factor for migration because the income structure is highly segmented between urban and rural areas. This segmentation can be appreciated mainly from wages, which represent $87 \%$ of the household income in Mexico. Frank Levy et al. (1995) argued that formation of salaries between urban and rural areas is dissimilar. Salaries in urban areas are a function of contracts, usually higher than minimum wages, and salaries in rural areas are determined by demand and supply of labour. The structure of both types of salaries makes income, prices and cost structures very different between regions.

Migration of indigenous people to Monterrey is a recent phenomenon. Alberto Valencia Rojas (2000) stated that the abandonment of the agricultural sector by the Mexican government has dramatically affected primary-sector activities, which has resulted in a massive flow of indigenous people to various cities, principally to Mexico City, Guadalajara and Monterrey. In this regard, Cecelia Sheridan (2000) noted that in the last three decades the phenomenon of indigenous migration to urban areas has increased, but this flow is more directed to northern cities; for example, Monterrey has become a new magnet for indigenous migrants. According to Durin et al. (2007) the presence of the indigenous population in Monterrey is more visible each day; it is not only because of growth in numbers, but also due to their concentration in certain marginalised sectors. The authors also argue that since the 1970s Monterrey has become very attractive for indigenous people due to the higher wages available compared to their place of origin and also an abundance of employment in the informal sector despite a lack of social security (Durin, 2003). Data show that the indigenous population in Monterrey increased greatly from 1970 to 2010. For example, in 1970 there were only 787 migrants, in 1990 there were 4,852 migrants and in 2010 there were 40,137 (INEGI, 2011).

Studies by Farfán and Fernández (2001), Wendolín Rodríguez (2002), Dzib (2003) and Durin (2003) indicate that the increase in the indigenous population has also corresponded to an increase in racial discrimination in Monterrey. According to Dzib (2003), Mixtec indigenous that reside

Table 1: Socio-demographic characteristics of indigenous migrants in Monterrey.

\begin{tabular}{ll}
\hline Characteristics & $\%$ \\
\hline Origin & 76.7 \\
\hline Rural & 23.3 \\
\hline Urban & \\
\hline Age & 27.2 \\
\hline $16-20$ & 37.8 \\
\hline $21-30$ & 19.1 \\
\hline $31-40$ & 15.9 \\
\hline$>40$ & \\
\hline Marital status & 43.9 \\
\hline Unmarried & 33.3 \\
\hline Married & 8.2 \\
\hline Single mother or father & 14.6 \\
\hline Other & \\
\hline Education & 3.9 \\
\hline Illiterate & 41.8 \\
\hline Primary & 38.2 \\
\hline Secondary & 16.1 \\
\hline$>$ Secondary & 12.7 \\
\hline Ethnic group & 5.6 \\
\hline Otomi & 62.0 \\
\hline Mazahua & 19.7 \\
\hline Nahua & Cho \\
\hline Other* & \\
\hline & \\
\hline
\end{tabular}

Note: $\left.{ }^{*}\right)$ Other includes Huastec, Nahuatlatoli, Ch'ol, Mixtec and Tepehua 
in Monterrey, especially schoolchildren, face discrimination because of their dress, skin colour and language. These children are referred to derogatorily as indillos or pedinches. Durin (2003) mentioned that domestic workers basically face a high degree of discrimination, primarily in the way indigenous women are treated.

\section{Socio-demographic characteristics of indigenous migrants}

As mentioned earlier, 350 indigenous migrants were interviewed in Monterrey. The results show that nearly $77 \%$ of them originated from rural areas and only $23 \%$ migrated from urban areas. This shows that most migration comes from rural areas. Similarly, the data indicate that the majority of the respondents are sixteen to thirty years old. This implies that there is a predominance of young migrants. In addition, nearly half of the migrants were unmarried and one-third of them were married. Forty-one percent of the indigenous migrants were educated up to the primary level and nearly $40 \%$ had a secondary education, but overall these indigenous migrants have little formal education. The analysis also shows that indigenous migrants in Monterrey belong to the Nahua ethnic group (62\%), and there is a presence of other ethnic groups such as Otomi, Mazahua, Mixtec and Huastec, among others (see Table 1, Figures 2 and 3).

\section{Factors and principal reasons related to migration to Monterrey}

As shown in Table 2, there are several reasons and factors that motivate indigenous people to migrate to Monterrey. The most important reason perceived by the migrants $(71 \%)$ was the absence of employment in their place of origin, and so they migrated to Monterrey in search of better employment with good pay. The second factor stated by the migrants was family. Four percent of migrants stated that their family economic condition was very critical; therefore they migrated to Monterrey in order to help their families pay off debt. It is also interesting to see that $5 \%$ of migrants indicated that they came to the city to seek higher education. This analysis strongly indicates that rural-to-urban migration is based on economic interest.

Table 2: Factors perceived in reasons for moving to Monterrey.

\begin{tabular}{ll}
\hline Reasons & $\%$ \\
\hline Seeking employment & 90.7 \\
\hline Poor family economic condition & 4.0 \\
\hline Study & 5.3 \\
\hline
\end{tabular}

\section{Employment pattern and economic benefits after migration}

Indigenous people started migrating in the colonial period. However, most migration has taken place during the twentieth century and the beginning of this century. This is basically due to the deterioration of rural and peasant economies, accompanied by the exponential growth of the informal economy in which numerous abuses are found, armed conflicts, the progressive loss of community lands, the lack of access to basic social services and the generalised increasing levels of poverty.
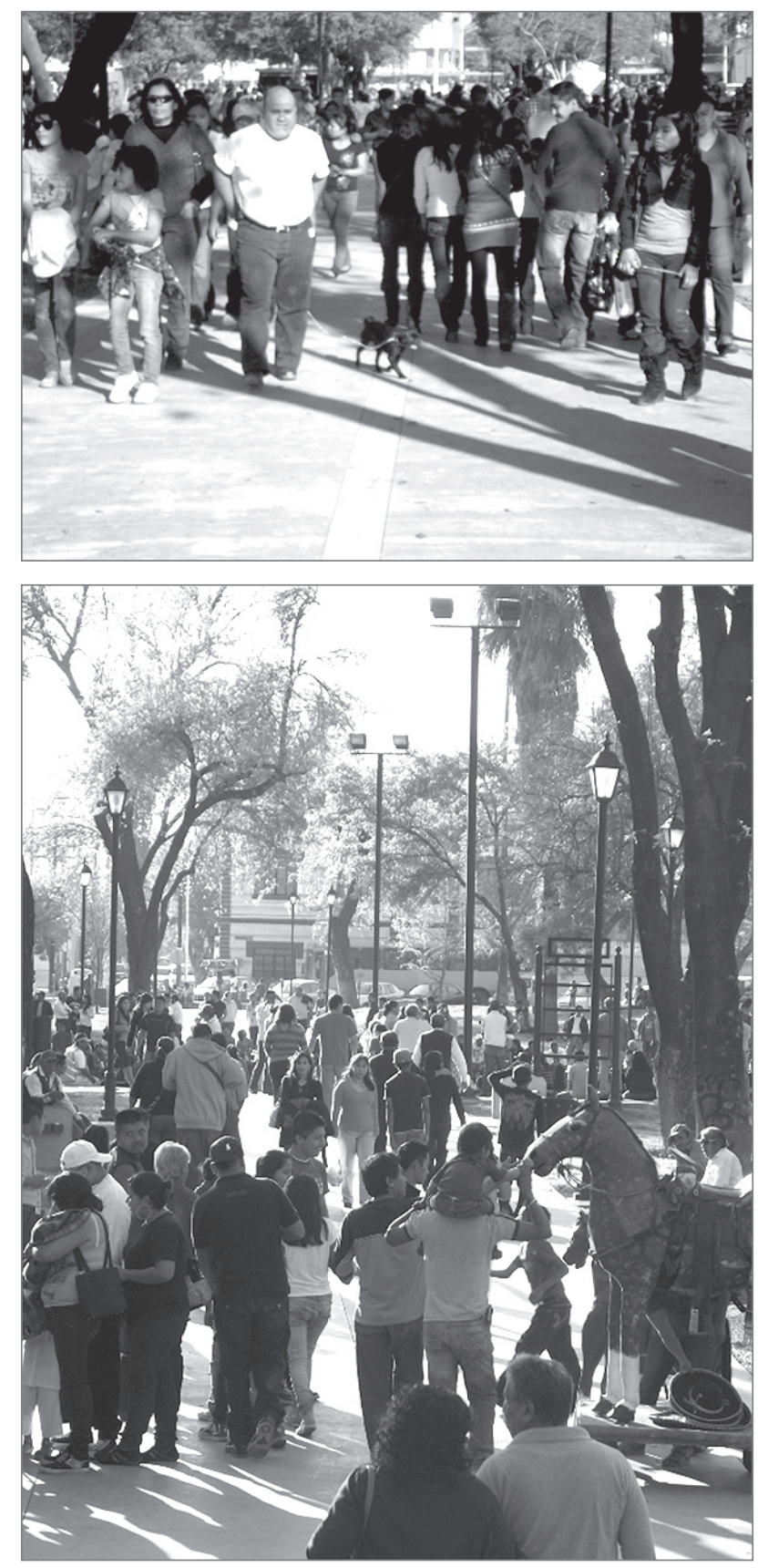

Figure 3: Indigenous people and migrants at Alameda, Monterrey (photo: Arun Kumar Acharya). 
Table 3: Employment and salary of migrants in Monterrey.

\begin{tabular}{ll}
\hline Type of Employment & $\%$ \\
\hline Seeking a job or unemployed & 14.1 \\
\hline Industry & 13.3 \\
\hline Construction & 15.0 \\
\hline Street vendor & 7.0 \\
\hline Domestic servant & 24.8 \\
\hline Restaurant and hotel & 24.0 \\
\hline Others & 2.0 \\
\hline Monthly salary & 1.8 \\
\hline$<$ MXN 2,000 & 4.8 \\
\hline MXN 2,001-4,000 & 76.4 \\
\hline MXN 4,001-8,000 & 17.0 \\
\hline$>$ MXN 8,000
\end{tabular}

One question that needs to be taken into account differentiating the study of indigenous migration from the general migratory tendency is the problem of indigenous migration being seen simply as a process driven by poverty, a lack of education or a disparity in employment opportunities. There are also important considerations in the complex decision to migrate that need to be taken into account that involve the loss of traditional lands.

During the interviews, we asked indigenous migrants some questions related to their employment patterns and economic benefits, which are presented in Table 3 . The results indicate that $14 \%$ of migrants are still seeking a job, whereas $86 \%$ are employed in various sectors, basically in informal markets. Migrants are mostly occupied in the industrial sector and construction; some also work as street vendors selling clothes, vegetables and other food. Nearly $50 \%$ of migrants work as domestic servants (mainly women) and in restaurants and hotels as cleaners, cooks and waiters. On the other hand, when we asked migrants about their monthly salary, only $2 \%$ of migrants earn less than MXN 2,000 (USD 166) ${ }^{[2]}$ per month and 5\% earn between MXN 2,000 and 4,000 (USD 166 to 333) per month. It is interesting to observe that the majority of migrants (76\%) earn around MXN 8,000 (USD 666) per month. When we asked the migrants whether moving to Monterrey has benefited them economically, the majority of them strongly agreed that it helped them improve their family's economic situation and also led to a better lifestyle.

\section{Discrimination against migrants and their social segregation}

Indigenous people that have migrated to cities have commonly found themselves on the fringes of society. The many reasons for this include discrimination, lack of marketable skills for city life, lack of formal education and language differences.
Table 4: Discrimination faced by migrants in Monterrey.

\begin{tabular}{ll}
\hline Discrimination & $\%$ \\
\hline Face discrimination & \\
\hline Yes & 89.2 \\
\hline No & 10.8 \\
\hline Reason for discrimination & \\
\hline Skin colour & 89.1 \\
\hline Not speaking Spanish & 40.3 \\
\hline Dress pattern & 72.8 \\
\hline Being a migrant & 91.2 \\
\hline Cultural differences & 66.5 \\
\hline
\end{tabular}

The hardships faced by indigenous persons in cities are directly related to their weak economic and social conditions. We asked migrants whether they have faced any kind of discrimination in Monterrey. Almost 90\% of them said that they have faced various kinds of discrimination. When we asked what the main reasons of discrimination are, migrants perceive that they face it because of their skin colour. Some migrants feel that it is because of their inability to speak Spanish well, and so people make fun of them or hate them. More than $70 \%$ of migrants (mainly female) say that this has happened because of the way they dress because indigenous women often wear their regional dress. Data indicate that more than $90 \%$ of migrants feel that they have been discriminated against socially and economically due to their status as migrants. Local people feel that migrants are criminals and that they are stealing their jobs, and some migrants also feel that they are discriminated against because of cultural differences (see Table 4).

As seen from the earlier discussion, indigenous migrants are discriminated against socially and economically in the city. We calculated and analysed the social segregation of these migrants. This analysis shows that discrimination against migrants leads to social segregation, presented in Table 5. To calculate social segregation, we examined seven aspects of migrants: a) migrants' friendship patterns, b) frequency of migrants' participation in community festivals, c) frequency of migrants' participation in non-community festivals, d) place of residence, e) whether the migrants struggle to find a job or not, $f$ ) migrants' shopping places and g) frequency of migrants' visits to a mall, museum or restaurant. Regarding the friendship pattern of migrants, $82 \%$ of indigenous migrants have friends within their community. Regarding friends outside their community or friendships with non-indigenous people, only $10 \%$ of migrants replied positively. Many migrants stated that this is because of discrimination; they also mentioned that it is hard to make friends with local people because of economic differences. On other hand, all migrants frequently participate in community festivals, whereas migrants very rarely participate in non-community festivals. Similarly, nearly $99 \%$ of indigenous migrants reside in peripheral areas of the city, and very 
Table 5: Index of social segregation faced by indigenous migrants in Monterrey.

\begin{tabular}{ll}
\hline Social segregation & $\%$ \\
\hline Friendship pattern & \\
\hline Friends within the community & 82.2 \\
\hline Friends outside the community & 10.0 \\
\hline Participation in community festivals & 100.0 \\
\hline Frequently & 0.0 \\
\hline Occasionally & 0.0 \\
\hline Never & \\
\hline Participation in non-community festivals & 1.0 \\
\hline Frequently & 23.3 \\
\hline Occasionally & 75.7 \\
\hline Never & \\
\hline Place of residence & 98.7 \\
\hline City periphery & 1.3 \\
\hline Inside the city & \\
\hline Struggle for employment & 97.2 \\
\hline Yes & 2.8 \\
\hline No & 0.6 \\
\hline Shopping & 2.5 \\
\hline Supermarket & 96.9 \\
\hline Community shop & 99.6 \\
\hline Street market & \\
\hline Visit mall, museum or restaurant & \\
\hline Frequently & \\
\hline Occasionally & \\
\hline Never & \\
\hline & \\
\hline & \\
\hline
\end{tabular}

few migrants reside inside the city. The main reason for this is that rentals are very cheap in the periphery and these areas are less urbanised, and so the existence of the rural environment attracts migrants to this place. Moreover, when we analysed whether migrants struggle to find jobs, we saw that for the majority of them it was not easy to find a job.

As the studies by Durin (2003), Dzib (2003) and Farfán and Fernández (2001) on indigenous migration in Nuevo León, especially to Monterrey, explained, due to fear of discrimination and violence migrants always keep away from the local environment, which can be corroborated by what we have seen for the indigenous migrants in Monterrey. When we asked migrants where they generally do their shopping, the vast majority of them stated that they go to community shops and street markets near their place of residence and few migrants mentioned supermarkets. In addition, indigenous migrants generally do not visit malls, museums or restaurants; $97 \%$ said they have never visited such places. Our analysis indicates that there is clear social segregation of indigenous migrants in Monterrey due to discrimination. Fear of discrimination is the main and most important reason for migrants to segregate themselves, even though they are natives of the country (see Table 5).

\section{Conclusion}

There are a number of studies on indigenous peoples' migration that have mainly concentrated on two types of movement: internal migration to cities and international migration. However, this study found that research on indigenous mobility and migration is very important for formulating different kinds of policies to improve the quality of life of this specific sector. As seen from the analysis, indigenous people move out of areas with high unemployment in search of a better lifestyle. The results indicate that lack of government policies to develop the rural sector and neglect of the agricultural sector are some of the principal reasons why indigenous people are suffering from poverty and unemployment. Although migrants feel that their economic condition improved after migrating to Monterrey, the study shows that indigenous people suffer significant social, economic, cultural and racial discrimination due to their indigenous and migrant status, as well as their inability to speak Spanish well and their style of dress.

The analysis showed that discrimination and fear of violence (physical, sexual) are some reasons for the social segregation of indigenous people. It is also seen that, although the migrants work inside the city, they prefer to settle on its periphery. Moreover, it is clear from the interviews that migrants prefer to have less contact with the local people, such as not making friends, not participating in local festivals and not visiting malls, supermarkets, museums, restaurants and so on. These findings indicate that Monterrey is currently a "divided" society even though the CDI is working hard to improve the quality of life of these migrants in Monterrey. Although it is promoting indigenous culture and indigenous rights, much still needs to be done in this regard. To sustain "social inclusion" it is important to educate people about equality and diversity at the elementary, high school and university levels because this will help prepare new generations to support and build an inclusive society for the future, without ethnic division or segregation.

To conclude, according to CDI Mexico, to date the government has presented eleven reports to the committee of the 1975 International Convention on the Elimination of All Forms of Racial Discrimination and is now awaiting the recommendation of the committee to move forward in protecting and promoting human rights among the Mexican people.

\section{Arun Kumar Acharya}

Institute for Social Science Research, Autonomous University of Nuevo León Av. Lázaro Cárdenas Ote. y Paseo de la Reforma S/N, Campus Mederos, Monterrey, Mexico

E-mail: acharya_77@yahoo.com

Manuel R. Barragán Codina

Institute for Social Science Research, Autonomous University of 
Nuevo León, Av. Lázaro Cárdenas Ote. y Paseo de la Reforma S/N, Campus Mederos, Monterrey, Mexico

\section{Notes}

${ }^{[1]}$ Alameda is located in the centre of Monterrey; it is a gathering place for indigenous people. During the weekend indigenous people come to this place to meet their friends and people from the community.

[2] USD 1 is roughly MXN 12 .

\section{References}

Ayman, G. Z. (2002) Rural to urban labor migration: A study of upper Egyptian laborers in Cairo. Doctoral thesis. University of Sussex, England.

Cornwell, K. \& Brett, I. (2004) Migration and unemployment in South Africa: When motivation surpasses the theory. Monash Econometrics and Business Statistics Working Papers, 4(2), pp. 1-29.

Cutler, D. M., Glaeser, E. L. \& Vigdor, J. L. (1999) The rise and decline of the American ghetto. Journal of Political Economy, 107(3), pp. 455-506. DOI: $10.1086 / 250069$

Del Popolo, F. (2007) Spatial distribution of indigenous peoples in Latin America: A census-based interpretation. Paper presented at the Expert Group Meeting on Urban Indigenous Peoples and Migration, 2729 March, Santiago, Chile. Typescript.

Durin, S. (2003) Nuevo León, Un Nuevo destino de la migración Indígena. Revista Antropología Experimental, 3, pp. 1-7.

Durin, S., Moreno, R. \& Sheridan, C. (2007) Rostros Desconocidos. Perfil socio demográfico de las Indígenas en Monterrey. Trayectorias, 9(23), pp. 29-42.

Dzib, N. H. (2003) Los Mixtecos en Nuevo León. Culturas Populares, April-June(1), pp. 11-23.

Farfán, O. \& Fernández, I. (2001) Identidad y conversión religiosa de los inmigrantes Otomíes. Cathedra, 1(3), September-December, Revista de la Facultad de Filosofía y Letras de la Universidad Autónoma de Nuevo León, pp. 77-85

Farley, R. \& Frey, W. H. (1994) Changes in the segregation of whites from blacks during the 1980s: Small steps toward a more integrated society. American Sociological Review, 59(1), pp. 23-45. DOI: $10.2307 / 2096131$

Fong, E. \& Gulia, M. (1999) Differences in neighborhood qualities among racial and ethnic groups in Canada. Sociological Inquiry, 69(4), pp. 575-598. DOI: 10.1111/j.1475-682X.1999.tb00887.x

Fox, J. \& Rivera Salgado, G. (2004) Building civil society among indigenous migrants. In: Fox, J. \& Rivera Salgado, G. (eds.) Indigenous Mexican migrants in the United States, La Jolla, pp. 1-9. San Diego, University of California, Center for Comparative Immigration Studies and Center for US-Mexican Studies.

Hall, G. \& Patrinos, H. (2005) Indigenous peoples, democracy and political participation. Available at: http://pdba.georgetown.edu (accessed 6 Mar. 2012

Husain, M. (1994) Human geography. Jaipur, Rawat Publications.

Immigration and Refugee Board of Canada (2008) Treatment of indigenous people in urban areas; State protection efforts (2005-2007). Available at: http://www.unhcr.org (accessed 29 Feb. 2012).

Instituto Nacional de Estadísticas y Geografía (2011) Perspectiva estadísticas de Nuevo León. Mexico City.

Internet 1: http://zemljevid.e-informacije.com (accessed 23 Apr. 2012) (accessed 12 Mar. 2012).

Kipuri, N. (2007) Urban indigenous African pastoralists: Distinct peoples with distinct needs. Paper presented at the Expert Group Meeting on Urban Indigenous Peoples and Migration, 27-29 March, Santiago, Chile. Typescript.

Lee, E. (1966) A theory of migration. Demography, 3(1), pp. 47-57. DOI: $10.2307 / 2060063$

Levy, F. (1995) Incomes and income inequality since 1970. In: Farley, R. (ed.) State of the union: America in the 1990s. Volume one: Economic trends, pp. 1-58. New York, Sage.

Márquez, F. (2011) Santiago: modernizacija, segregacija in urbane identitete v 21. stoletju [Santiago: Modernisation, segregation and urban identities in the twenty-first century]. Urbani izziv, 22(2), pp. 14-24 [86-97]. DOI: 10.5379/urbani-izziv-en-2011-22-02-002

Massey, D. S. \& Denton, N. A. (1985) Spatial assimilation as a socioeconomic outcome. American Sociological Review, 50(1), pp. 94-106. DOI: $10.2307 / 2095343$

Massey, D. S. \& Denton, N. A. (1988) Trends in the residential segregation of Blacks, Hispanics, and Asians: 1970-1980. American Sociological Review, 52(6), pp. 802-825. DOI: 10.2307/2095836

Massey, D. S. \& Denton, N. A. (1993) American apartheid: Segregation and the making of the underclass. Cambridge, MA, Harvard University Press.

Mere, F. (2007) Rural migration in México: An overview. Paper presented at the Agricultural Outlook Forum of the United States Department of Agriculture, 1-2 March, Arlington, Virginia, USA. Typescript.

Pérez Ruiz, M. L. (2007) Metropolitanismo, globalización y migración indígena en las ciudades de México, VillaLibre, 1, pp. 68-94.

Population Reference Bureau (2012) Human Population: Urbanization. Available at: http://www.prb.org (accessed 21 Feb. 2012).

Rodríguez, W. (2002) La construcción de la identidad en Indígenas migrantes. Un estudio de casos: los mixtecos en Juárez, Nuevo León. Bachelor's thesis. San Nicolás de los Garza, Universidad Autónoma de Nuevo León, Facultad de Filosofia y Letras.

Rojas, A. V. (2000) La migración Indígena a las ciudades. Mexico City, Instituto Nacional de Indigenista.

Sema, K. E. (2007) Indigenous peoples in India: Struggle for identity, equality and economic progress. Paper presented at the Expert Group Meeting on Urban Indigenous Peoples and Migration, 27-29 March, Santiago, Chile. Typescript.

Sheridan, C. (2000) Anónimos y desterrados. La contienda por el "sitio que Ilaman de Quauyla" Siglo XVI-XVIII. Mexico City, CIESAS.

Taeuber K. E. \& Taeuber, A. F. (1965) Negroes in cities: Residential segregation and neighborhood change. West Hanover, MA, Atheneum.

Todaro, M. P. (1976) Internal migration in developing countries: A review of theory, evidence, methodology and research priorities. Geneva, International Labour Office.

United Nations (2010) World population prospects: The 2010 revision. New York.

United Nations Human Settlements Program (2007) Policy makers guide to women's land, property and housing rights across the world. Nairobi, Kenya.

United Nations Human Settlements Program (2010) Urban indigenous peoples and migration: A review of policies, programs and practices. Nairobi, Kenya.

United Nations Permanent Forum on Indigenous Issues (2008) Indigenous peoples in the Pacific region. Paper presented at the United Nations Permanent Forum on Indigenous Issues, 21 Apr.-2 May, New York. Typescript.

White, M. J. (1986) Segregation and diversity measures in population distribution. Population Index, 52(2), pp. 198-221. DOI: 10.2307/3644339 